\title{
Transamination-Like Reaction Catalyzed by Leucine Dehydrogenase for Efficient Co-Synthesis of $\alpha$-Amino Acids and $\alpha$-Keto Acids
}

\author{
Xiaoqing Mu ${ }^{1,2,3, *(D)}$, Xian Feng ${ }^{1}$, Tao $W^{1}{ }^{1}$, Feng Zhou ${ }^{1}$, Yao Nie ${ }^{1}$ (D) and Yan Xu ${ }^{1}$ \\ 1 Laboratory of Brewing Microbiology and Applied Enzymology, School of Biotechnology, Jiangnan University, \\ Wuxi 214122, China; fx2691695431@163.com (X.F.); 7200201064@stu.jiangnan.edu.cn (T.W.); \\ 7170201062@stu.jiangnan.edu.cn (F.Z.); ynie@jiangnan.edu.cn (Y.N.); yxu@jiangnan.edu.cn (Y.X.) \\ 2 Key Laboratory of Industrial Biotechnology, Ministry of Education, School of Biotechnology, \\ Jiangnan University, Wuxi 214122, China \\ 3 Institute of Industrial Technology, Suqian Jiangnan University, Suqian 223800, China \\ * Correspondence: xqmu@jiangnan.edu.cn
}

Citation: Mu, X.; Feng, X.; Wu, T.; Zhou, F.; Nie, Y.; Xu, Y.

Transamination-Like Reaction Catalyzed by Leucine Dehydrogenase for Efficient Co-Synthesis of $\alpha$-Amino Acids and $\alpha$-Keto Acids. Molecules 2021, 26, 7287. https://doi.org/ $10.3390 /$ molecules 26237287

Academic Editor: Giorgos Markou

Received: 29 October 2021

Accepted: 27 November 2021

Published: 30 November 2021

Publisher's Note: MDPI stays neutral with regard to jurisdictional claims in published maps and institutional affiliations.

Copyright: (c) 2021 by the authors. Licensee MDPI, Basel, Switzerland. This article is an open access article distributed under the terms and conditions of the Creative Commons Attribution (CC BY) license (https:/ / creativecommons.org/licenses/by/ $4.0 /)$.

\begin{abstract}
Amino acids and $\alpha$-keto acids are versatile building blocks for the synthesis of several commercially valuable products in the food, agricultural, and pharmaceutical industries. In this study, a novel transamination-like reaction catalyzed by leucine dehydrogenase was successfully constructed for the efficient enzymatic co-synthesis of $\alpha$-amino acids and $\alpha$-keto acids. In this reaction mode, the $\alpha$-keto acid substrate was reduced and the $\alpha$-amino acid substrate was oxidized simultaneously by the enzyme, without the need for an additional coenzyme regeneration system. The thermodynamically unfavorable oxidation reaction was driven by the reduction reaction. The efficiency of the biocatalytic reaction was evaluated using 12 different substrate combinations, and a significant variation was observed in substrate conversion, which was subsequently explained by the differences in enzyme kinetics parameters. The reaction with the selected model substrates 2-oxobutanoic acid and L-leucine reached $90.3 \%$ conversion with a high total turnover number of $9.0 \times 10^{6}$ under the optimal reaction conditions. Furthermore, complete conversion was achieved by adjusting the ratio of addition of the two substrates. The constructed reaction mode can be applied to other amino acid dehydrogenases in future studies to synthesize a wider range of valuable products.
\end{abstract}

Keywords: transamination-like reaction; leucine dehydrogenase; $\alpha$-amino acids; $\alpha$-keto acids; cosynthesis

\section{Introduction}

$\alpha$-Amino acids, especially natural $\alpha$-amino acids, are the main building blocks of proteins and precursors for the synthesis of secondary metabolites, and play an indispensable role in the progress of various areas of life sciences [1]. $\alpha$-keto acids, which possess a keto group adjacent to the carboxylic acid, also play a central role in cell metabolism [2]. Moreover, both $\alpha$-amino acids and $\alpha$-keto acids are important intermediates in the pharmaceutical, food, cosmetic, agricultural, and animal feed industries [3-6]. The synthesis of $\alpha$-amino acids and $\alpha$-keto acids can be achieved using chemical [7-10] or biocatalytic methods [11-14]. Compared with chemical methods, biocatalytic synthesis is an attractive approach providing the advantages of low cost, mild conversion conditions, and green production credentials, and has gained increasing research interest [15-18].

$\alpha$-Amino acids and $\alpha$-keto acids can be starting substrates for each other's synthesis through transamination reactions $[19,20]$. The transaminase enzyme mediates the transfer of an amino group from the amino donor to the acceptor for the simultaneous synthesis of an $\alpha$-amino acid and $\alpha$-keto acid in a single reaction with a high atom and step economy, making it the biocatalyst of choice for academic research as well as industrial applications [21]. However, the substrate specificities and catalytic efficiency of transaminase in 
reversible reactions need to be investigated thoroughly to meet the demands of industrial processes [22]. Amino acid dehydrogenase is another potential enzyme that can be used for $\alpha$-amino acid or $\alpha$-keto acid synthesis via reductive amination or oxidative deamination reaction [23-27]. However, amino acid dehydrogenase thermodynamically favors the reductive amination reaction of $\alpha$-keto acids, which uses the expensive coenzyme NADH as a reducing agent $[28,29]$. This necessitates the coupling of the amino acid dehydrogenase with an additional enzyme such as glucose dehydrogenase (GDH) or formate dehydrogenase (FDH) to regenerate NADH and improve the total turnover number (TTN) [30-33], which increases the cost and complexity of the process.

Thus, to facilitate the simultaneous synthesis of $\alpha$-amino acids and $\alpha$-keto acids in a single self-sustaining reaction, we attempted to construct a novel transamination-like reaction catalyzed by an amino acid dehydrogenase by coupling the oxidative deamination of an amino acid and the reductive amination of a keto acid (Figure 1). In this reaction, the rate of the thermodynamically unfavorable oxidation reaction matches that of the reduction reaction driven by the coenzyme NADH. Moreover, no coenzyme regeneration system is needed in this reaction owing to the complementary coenzyme dependence of the reduction and oxidation reactions. Both the reduced and oxidized forms of the coenzyme are quickly utilized in the transamination-like reaction until the reaction equilibrium is reached.
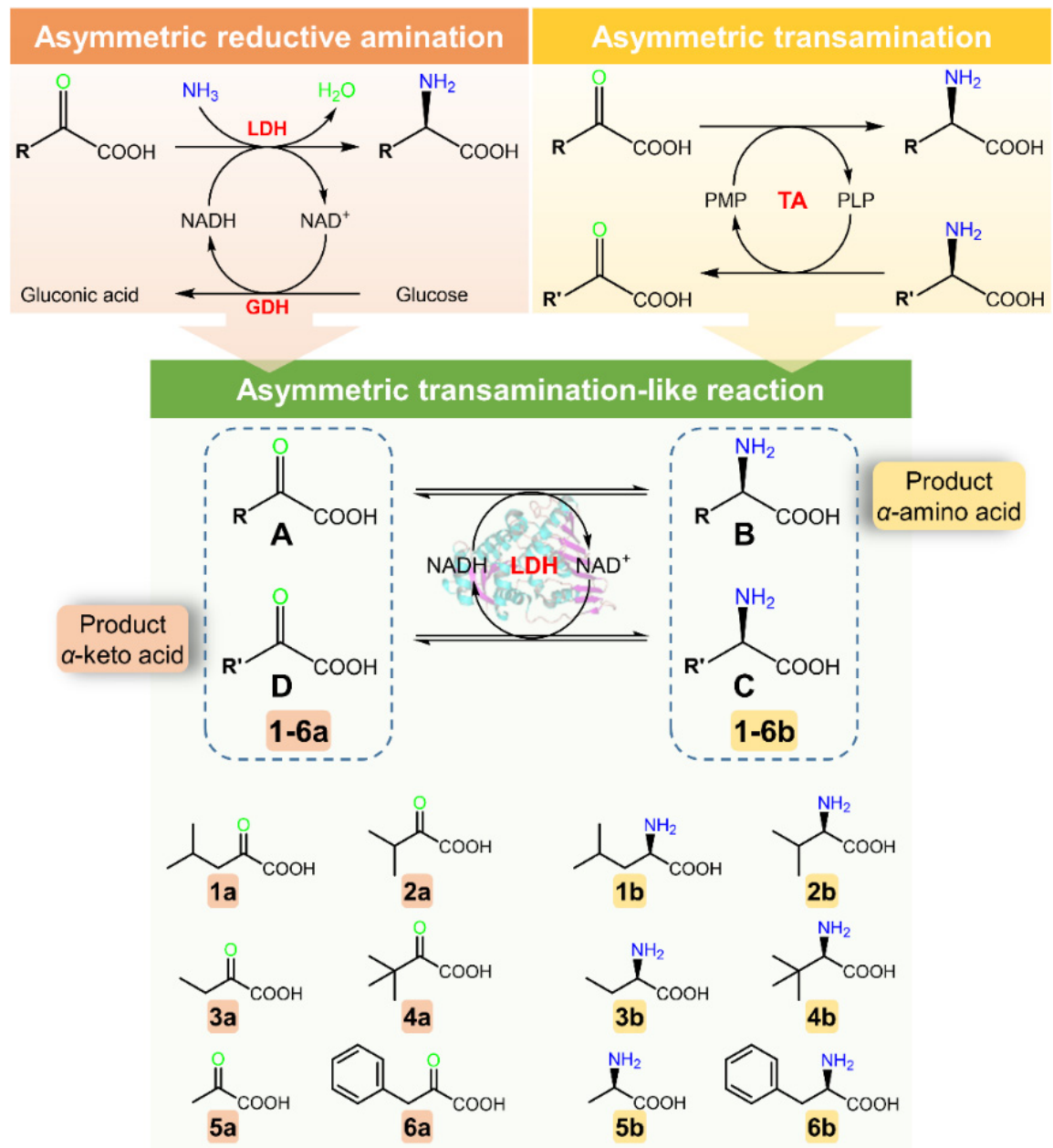

Figure 1. Schematic representation of reaction pathway of transamination-like reaction.

Leucine dehydrogenase (LDH) uses NADH or NAD to catalyze the reversible transformation between the natural substrates 4-methyl-2-oxopentanoic acid and L-leucine [24,26], and has been reported to be a crucial enzyme in the synthesis of commercially valuable $\alpha$-amino acids such as L-2-aminobutyric acid [28,34] and L-tert-leucine [30,31]. In the present study, 
LDH from Bacillus cereus [29] was chosen to construct a transamination-like reaction for the simultaneous synthesis of $\alpha$-amino acids and $\alpha$-keto acids (Figure 1 ). Twelve combinations of substrates, selected based on LDH specificity, were evaluated for transformation via the single-step transamination-like reaction. Enzyme kinetics were analyzed to clarify the effect of the different combinations of amino acceptors and donors on the eventual conversion. Furthermore, the reaction conditions and substrate proportions were optimized for maximum conversion of the model substrates 2-oxobutanoic acid (3a) and L-leucine (1b).

\section{Results and Discussion}

\subsection{Substrate Specificity of LDH toward $\alpha$-Amino Acids and $\alpha$-Keto Acids}

To characterize the substrate specificity of LDH, $\alpha$-keto acids (4-methyl-2-oxopentanoic acid, 1a; 3-methyl-2-oxobutanoic acid, 2a; 2-oxobutanoic acid, 3a; 3,3-dimethyl-2-oxobutanoic acid, 4a; 2-oxopropanoic acid, 5a; 2-oxo-3-phenylpropanoic acid, 6a) and $\alpha$-amino acids (L-leucine, 1b; L-valine, 2b; L-2-aminobutyric acid, 3b; L-tert-leucine, 4b; L-alanine, 5b; Lphenylalanine, $6 \mathrm{~b}$ ) were chosen for catalytic activity investigation. Consistent with previous literature reports, $\mathrm{LDH}$ showed measurable activity toward the aliphatic $\alpha$-amino acids $1 \mathrm{a}$ to 5 a and no activity toward the aromatic 2-oxo-3-phenylpropanoic acid (6a) (Figure 2) in the reduction direction [35]. Moreover, LDH reversibly catalyzed the conversion of a series of aliphatic $\alpha$-keto acids ( $1 b$ to $5 b$ ) to $\alpha$-amino acids, (Figure 2 ) as an aminotransferase. However, $\alpha$-aminotransferases usually require amino acids as amino donors for $\alpha$-keto acid reduction, and the conversion rate of the amino transfer reaction is restricted by thermodynamic equilibrium. In contrast, LDH can use the cheap and easily available ammonia as an amino donor to catalyze the reductive amination of $\alpha$-keto acids with a high atom economy.

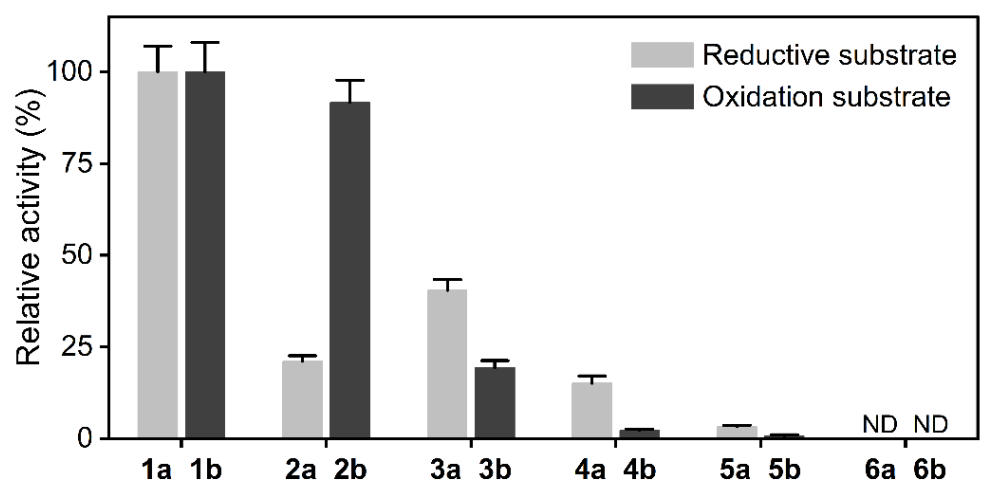

Figure 2. Relative activity of leucine dehydrogenase on $\alpha$-amino acids and $\alpha$-keto acids.

Activity was measured with $5 \mathrm{mM}$ substrate and $0.2 \mathrm{mM}$ coenzyme at $30{ }^{\circ} \mathrm{C}$ and carried out at a $200-\mu \mathrm{L}$ scale in 96 -well microtiter plates by monitoring the initial decrease or increase velocity of the absorbance at $340 \mathrm{~nm}$. The specific activity of the reductive substrates and the oxidation substrates were calculated with $1 \mathrm{a}$ and $1 \mathrm{~b}$ as the maximum activity, respectively. ND: no detectable activity. All determinations were performed in triplicate, and error bounds represent $\pm \mathrm{sd}$.

\subsection{Conversion of Single-Step Oxidation and Reduction Reactions Catalyzed by LDH}

The extent of conversion during the reaction was not only decided by the specific activity of the LDH enzyme, but also influenced by the reaction conditions. Both the reduction reactions of $5 \alpha$-keto acids and oxidation reactions of the five corresponding $\alpha$-amino acids were investigated. As shown in Figure 3, the conversion of the single-step oxidation reaction catalyzed by LDH were low, and did not exceed approximately 3\%, whereas the conversion of the single-step reduction reaction reached approximately $70 \%$. The conversion of the reduction reaction was nearly 23-fold higher than that of oxidative deamination, which indicated that LDH favors the reductive amination of $\alpha$-keto acid to the corresponding $\alpha$-amino acid. 

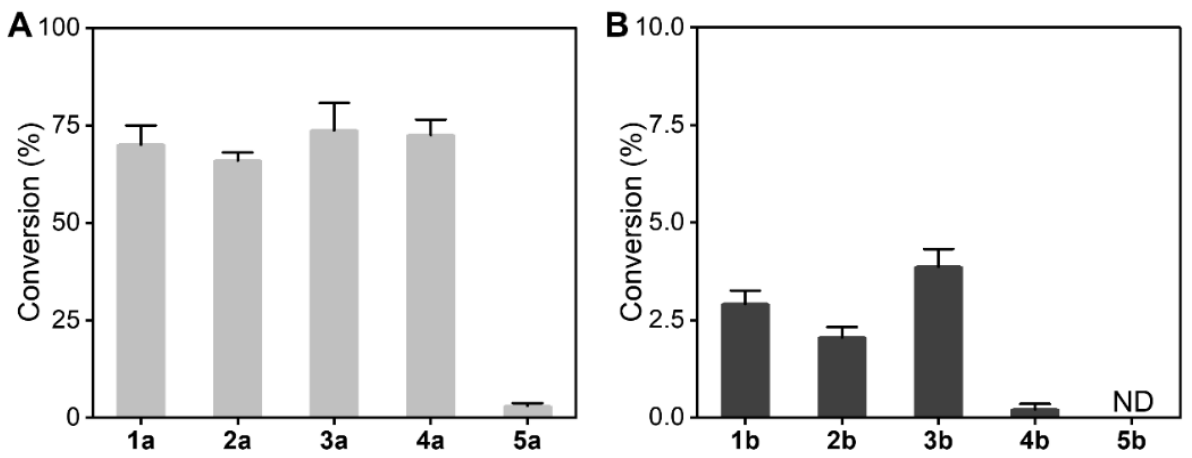

Figure 3. Single-step conversion experiment. (A): Conversion of different $\alpha$-keto acids by LDH, (B): conversion of corresponding $\alpha$-amino acids by LDH.

Reductive amination conditions: The total volume of the biocatalytic reaction mixture was $2 \mathrm{~mL}$. It contained $10 \mathrm{mM} \alpha$-keto acids, $10 \mathrm{mM} \mathrm{NAD}{ }^{+}, 1.0 \mathrm{mg} \cdot \mathrm{mL}^{-1}$ of purified $\mathrm{LDH}$, and $1 \mathrm{M} \mathrm{NH}_{4} \mathrm{Cl} / \mathrm{NH}_{4} \mathrm{OH}$ buffer ( $\mathrm{pH}$ 9.5). Oxidative deamination conditions: The total volume of the biocatalytic reaction mixture was $2 \mathrm{~mL}$. It contained $10 \mathrm{mM} \alpha$-amino acids, $10 \mathrm{mM} \mathrm{NADH}, 1.0 \mathrm{mg} \cdot \mathrm{mL}^{-1}$ of purified $\mathrm{LDH}$, and $0.1 \mathrm{M}$ Tris- $\mathrm{HCl}$ buffer (pH 8.5). The reaction mixture was incubated at $30{ }^{\circ} \mathrm{C}$ with shaking at $200 \mathrm{rpm}$ for $12 \mathrm{~h}$. All determinations were performed in triplicate, and error bounds represent $\pm \mathrm{sd}$.

\subsection{Effect of Different Combinations of Amino Group Donor and Acceptor on Conversion Rate}

Although LDH showed low activities and conversion on $\alpha$-amino acids, the enzyme could be used to oxidize the amino acids to produce keto acids when driven by coupling a high-efficiency coenzyme regeneration system. Based on the mechanism of the transamination reaction, a substrate-coupled transamination-like reaction catalyzed by LDH was established using the reduction of keto acid as a coupled coenzyme regeneration system to promote the oxidation reaction. The coenzyme dependence of reductive amination was complementary to that of oxidative deamination, providing an easy route for sustained coenzyme regeneration.

Based on the substrate specificity of LDH and conversion of single-step oxidation or reduction reactions, keto acid substrates $(1 \mathrm{a}, 2 \mathrm{a}, 3 \mathrm{a}$, and $4 \mathrm{a})$ and the corresponding amino acid substrates $(1 b, 2 b, 3 b$, and $4 b)$ were chosen to design 12 combinations of amino group donors and acceptors. The conversion of reactions employing the different substrate combinations are shown in Figure 4. On coupling with the reductive amination reaction, the conversion of most of the oxidation reactions increased to varying degrees compared with those of the single-step reaction. These results confirmed the feasibility of using the LDH-catalyzed transamination-like reaction for the simultaneous synthesis of $\alpha$-amino acids and $\alpha$-keto acids.

When $4 \mathrm{~b}$ participated in the reaction, the conversion of the all keto acid substrates tested (1a, 2a, and 3a) improved considerably. The conversion of $4 \mathrm{~b}$ reached $77.8 \%$, which is 77 times higher than its conversion in the single-step oxidation reaction. In contrast, when 4 a participated in the reaction, the conversion of the different amino acid substrates $(1 b, 2 b$, and $3 b)$ did not show a substantial increase. Nevertheless, the conversion of $4 \mathrm{~b}$ reached $22.6 \%$, which is still 7.8 times higher than that achieved in the single-step oxidation reaction.

The total volume of the biocatalytic reaction mixture was $2 \mathrm{~mL}$. It contained $10 \mathrm{mM}$ $\alpha$-amino acids, $10 \mathrm{mM} \alpha$-keto acids, $0.2 \mathrm{mM} \mathrm{NAD}{ }^{+}, 1.0 \mathrm{mg} \cdot \mathrm{mL}^{-1}$ of purified $\mathrm{LDH}, 1 \mathrm{M}$ $\mathrm{NH}_{4} \mathrm{Cl}$, and $0.1 \mathrm{M}$ Tris- $\mathrm{HCl}$ buffer ( $\mathrm{pH}$ 9.0). The reaction mixture was incubated at $30{ }^{\circ} \mathrm{C}$ with shaking at $200 \mathrm{rpm}$ for $12 \mathrm{~h}$. All determinations were performed in triplicate, and error bounds represent \pm sd. 


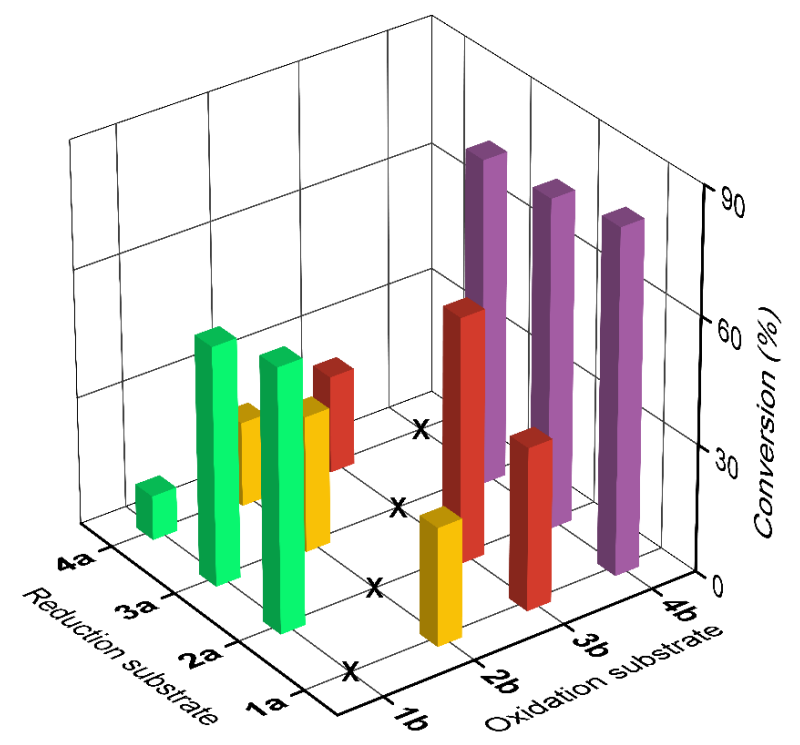

Figure 4. Conversion for reactions employing combinations of oxidation substrate and reduction substrate.

\subsection{Kinetic Parameters of LDH on Different Substrate}

To explore the reasons for the difference in conversion of different substrate combinations, the kinetic parameters of $\mathrm{LDH}$ for the reduction of $1 \mathrm{a}, 2 \mathrm{a}, 3 \mathrm{a}$, and $4 \mathrm{a}$ and oxidation of $1 b, 2 b, 3 b$, and $4 b$ were investigated.

As shown in Table 1 , the $k_{\text {cat }} / K_{\mathrm{m}}$ of LDH for different keto acids decreased in the sequence $1 \mathrm{a}>2 \mathrm{a}>3 \mathrm{a}>4 \mathrm{a}$ in the reductive amination reaction, and $k_{\text {cat }} / K_{\mathrm{m}}$ decreased in a similar sequence for the corresponding amino acids in the oxidative deamination reaction. The $k_{\text {cat }} / K_{\mathrm{m}}$ values of the reduction reactions were 2-3 orders of magnitude higher than that of the oxidation reactions, which explains why LDH favors catalyzing the reductive amination reaction. The kinetic parameters of different reduction or oxidation substrates and the conversion of reactions employing different substrate combinations suggested that the transamination-like reaction followed the following rules.

Table 1. Kinetic parameters of His-tagged LDH for both oxidative deamination and reductive amination.

\begin{tabular}{cccc}
\hline Substrate & $\boldsymbol{K}_{\mathbf{m}} \mathbf{( m M )}$ & $\boldsymbol{k}_{\text {cat }}\left(\mathbf{s}^{-\mathbf{1}}\right)$ & $\boldsymbol{k}_{\text {cat }} / \boldsymbol{K}_{\mathbf{m}}\left(\mathbf{m M} \cdot \mathbf{s}^{-\mathbf{1})}\right.$ \\
\hline $\mathbf{1 a}$ & $1.16 \pm 0.37$ & $167.25 \pm 10.23$ & $143.69 \pm 6.36$ \\
$\mathbf{2 a}$ & $1.41 \pm 0.19$ & $73.20 \pm 4.17$ & $51.92 \pm 1.57$ \\
$\mathbf{3 a}$ & $2.38 \pm 0.54$ & $62.29 \pm 4.32$ & $26.14 \pm 0.58$ \\
$\mathbf{4 a}$ & $9.15 \pm 1.23$ & $16.79 \pm 2.56$ & $1.84 \pm 0.32$ \\
$\mathbf{1 b}$ & $0.86 \pm 0.21$ & $0.25 \pm 0.03$ & $0.29 \pm 0.03$ \\
$\mathbf{2 b}$ & $2.31 \pm 0.11$ & $0.17 \pm 0.01$ & $0.07 \pm 0.001$ \\
$\mathbf{3 b}$ & $30.04 \pm 1.39$ & $0.16 \pm 0.06$ & $0.005 \pm 0.001$ \\
$\mathbf{4 b}$ & $16.26 \pm 0.86$ & $0.05 \pm 0.01$ & $0.003 \pm 0.002$ \\
$\mathrm{NAD}$ & $0.25 \pm 0.04$ & $1.07 \pm 0.249$ & $2.08 \pm 0.16$ \\
$\mathrm{NADH}$ & $0.19 \pm 0.03$ & $2.90 \pm 0.78$ & $5.64 \pm 0.23$ \\
\hline
\end{tabular}

Steady-state kinetic parameters were determined by varying the concentration of the substrate $(0.1-50 \mathrm{mM})$ to be measured in the presence of fixed concentrations of the coenzyme $\left(0.5 \mathrm{mM} \mathrm{NAD}^{+}\right.$in the oxidative deamination and $0.5 \mathrm{mM} \mathrm{NADH})$ and cosubstrate ( $1 \mathrm{M}$ ammonia in the reductive amination) at $30^{\circ} \mathrm{C}$ and carried out at a $200-\mu \mathrm{L}$ scale in 96 -well microtiter plates by monitoring the initial decrease or increase velocity of the absorbance at $340 \mathrm{~nm}$. All determinations were performed in triplicate, and error bounds represent $\pm \mathrm{sd}$.

As shown in Figure 1, the conversion efficiency of the transamination-like reaction was determined by the ratio of the $k_{\mathrm{cat}} / K_{\mathrm{m}}$ of the reduction reaction substrate (A) and the $k_{\mathrm{cat}} / K_{\mathrm{m}}$ of the reduction product corresponding to the oxidation reaction substrate 
(D). A higher ratio resulted in a higher conversion efficiency. If the catalytic efficiency in the reaction from $A$ to $B$ was greater than that in the reaction from $D$ to $C$, substrate $A$ preferentially bound the NADH coenzyme to prevent the reduction reaction of product D.

\subsection{Optimization of Conditions for the Transamination-Like Reaction}

Through comprehensive consideration of conversion and product value, the substrate combination of 2-oxobutyric acid (3a) and L-leucine (1b) was investigated as a substrate mode reaction. The reaction conditions, including coenzyme concentration, $\mathrm{NH}_{4}{ }^{+}$concentration, $\mathrm{pH}$, and substrate concentration, were optimized.

The effect of $\mathrm{NAD}^{+}$concentration on the conversion of the transamination-like reaction system is shown in Figure $5 \mathrm{~A}$. When the coenzyme concentration varied from $0.01 \mu \mathrm{M}$ to $10 \mu \mathrm{M}$, the TTN of the reaction dropped sharply, whereas the conversion of $3 \mathrm{a}$ and $1 \mathrm{~b}$ did not change substantially. When the concentration of coenzyme was $0.01 \mu \mathrm{M}$, the conversion of $3 \mathrm{a}$ and $1 \mathrm{~b}$ reached $58.8 \%$ and $65.6 \%$, respectively, with a high TTN of $5.9 \times 10^{5}$. This shows that the concentration of coenzyme has a negligible impact on the final conversion in transamination-like reactions, as both the oxidized and reduced forms of the coenzyme would be consumed quickly by oxidation or reduction reactions. Thus, a coenzyme selfcycle was built in transamination-like reactions.
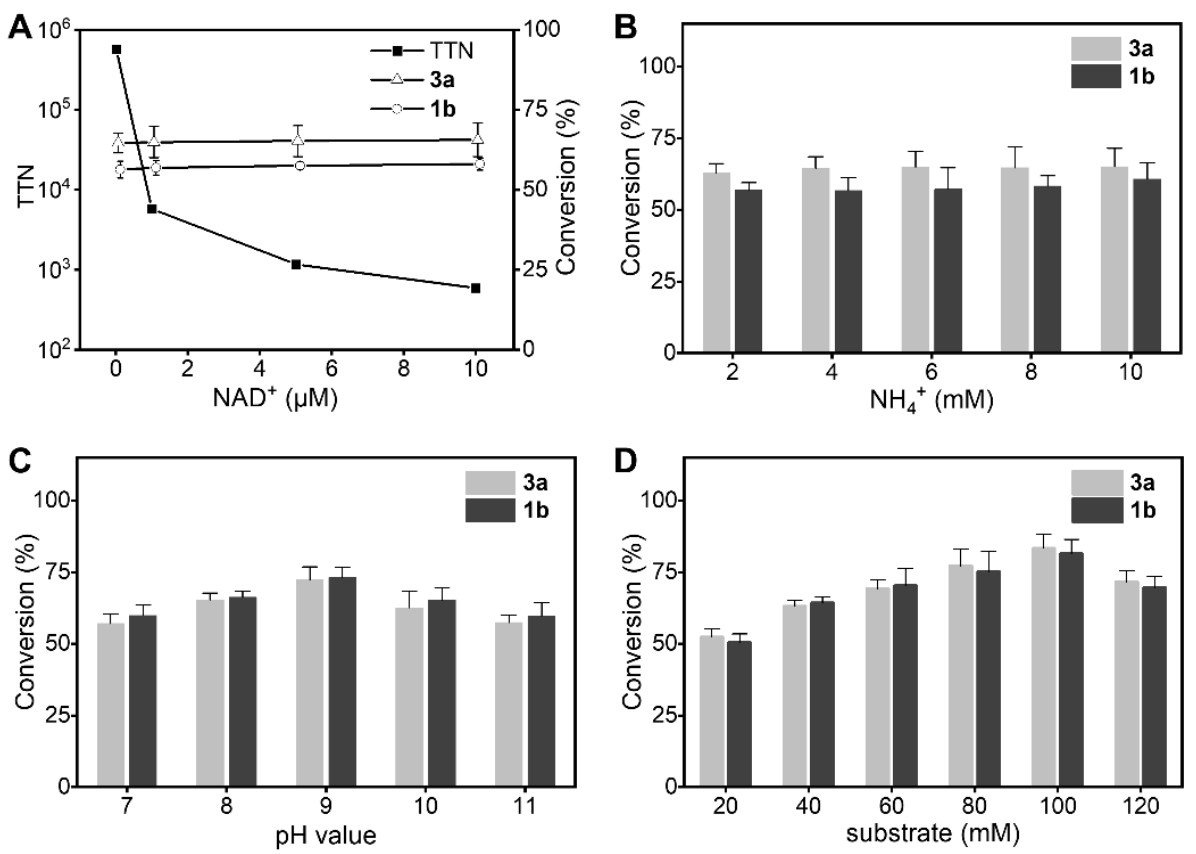

Figure 5. Effect of $\mathrm{NAD}^{+}$concentration (A), $\mathrm{NH}_{4}{ }^{+}$concentration (B), $\mathrm{pH}$ value (C), and substrate concentration $(\mathbf{D})$ in the transamination-like reaction involving substrates $3 \mathrm{a}$ and $1 \mathrm{~b}$.

Studying the effect of $\mathrm{NH}_{4}{ }^{+}$concentrations from $2 \mathrm{mM}$ to $10 \mathrm{mM}$ revealed that $\mathrm{NH}_{4}{ }^{+}$ had almost no effect on the transamination-like reaction (Figure $5 \mathrm{~B}$ ). $\mathrm{NH}_{4}{ }^{+}$is the product of the oxidation reaction and can be used as an amino group donor during the transaminationlike reaction. Therefore, $2 \mathrm{mM}$ was decided as the optimal $\mathrm{NH}_{4}^{+}$concentration for the transamination reaction.

The reaction $\mathrm{pH}$ was varied from 7.0 to 11.0 to evaluate its effect on the conversion. As shown in Figure 5C, the conversion rate increased with an increase in the $\mathrm{pH}$ range from 7.0 to 9.0. Maximum conversions of $73.2 \%$ and $72.3 \%$ were achieved with $3 a$ and $1 b$, respectively, at $\mathrm{pH}$ 9.0. The conversion rate dropped beyond $\mathrm{pH} 9.0$, which may be due to enzyme denaturation and inactivation at high $\mathrm{pH}$ values. Therefore, $\mathrm{pH} 9.0$ was selected as the optimal $\mathrm{pH}$ value for the transamination reaction.

As shown in Figure 5D, the effect of initial substrate concentration on conversion was studied in the range $20-100 \mathrm{mM}$. The conversion of $3 \mathrm{a}$ and $1 \mathrm{~b}$ reached maximum 
values of $83.4 \%$ and $81.5 \%$, respectively, with $100 \mathrm{mM}$ initial substrate concentration. The conversion decreased when a substrate concentration of $120 \mathrm{mM}$ was used, indicating that high substrate concentrations inhibit the reaction. Therefore, $100 \mathrm{mM}$ was chosen as the optimal substrate concentration for further transamination-like reactions.

The total volume of the biocatalytic reaction mixture was $2 \mathrm{~mL}$. It contained purified $\mathrm{LDH}\left(1.0 \mathrm{mg} \cdot \mathrm{mL}^{-1}\right), \mathrm{NAD}^{+}(0.01-10 \mu \mathrm{M}), \mathrm{NH}_{4} \mathrm{Cl}(2-10 \mathrm{mM})$, tris-HCl buffer ( $\left.\mathrm{pH} 7.0-9.0\right)$ or $\mathrm{NH}_{4} \mathrm{Cl} / \mathrm{NH}_{4} \mathrm{OH}$ ( $\left.\mathrm{pH} 10.0-11.0\right)$, and substrates (20-120 mM). The reaction mixture was incubated at $30^{\circ} \mathrm{C}$ with shaking at $200 \mathrm{rpm}$ for $12 \mathrm{~h}$. All determinations were performed in triplicate, and error bounds represent $\pm \mathrm{sd}$.

Under the optimal reaction conditions, the initial reaction rate was quite high and the conversion reached $75 \%$ in the first $2 \mathrm{~h}$. Subsequently, the reaction slowed down, with the final conversion of $1 \mathrm{~b}$ and $3 a$ reaching $90.3 \%$ and $89.5 \%$, respectively. In addition, the TTN increased from $5.9 \times 10^{5}$ to $9.0 \times 10^{6}$ compared with the previous reaction. However, the conversion did not reach $100 \%$ even on extending the reaction time, probably owing to the influence of thermodynamic equilibrium (Figure 6).

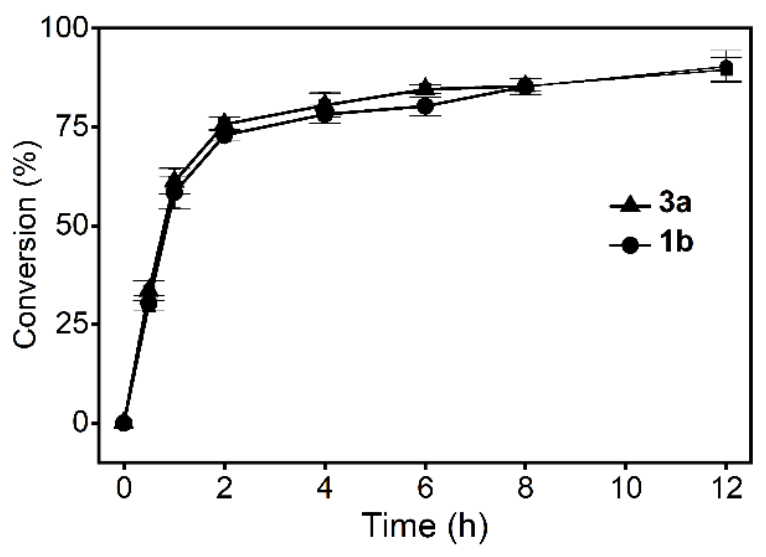

Figure 6. Reaction progress curve under optimal conditions.

The total volume of the biocatalytic reaction mixture was $2 \mathrm{~mL}$. It contained purified $\mathrm{LDH}\left(1.0 \mathrm{mg} \cdot \mathrm{mL}^{-1}\right), \mathrm{NAD}^{+}(0.01 \mu \mathrm{M}), \mathrm{NH}_{4} \mathrm{Cl}(2 \mathrm{mM})$, tris- $\mathrm{HCl}$ buffer ( $\left.\mathrm{pH} 9.0\right)$, and substrates $(100 \mathrm{mM})$. The reaction mixture was incubated at $30^{\circ} \mathrm{C}$ with shaking at $200 \mathrm{rpm}$ for $0-12 \mathrm{~h}$. All determinations were performed in triplicate, and error bounds represent $\pm \mathrm{sd}$.

\subsection{Shifting Reaction Equilibrium by Adjusting the Substrate Ratio}

Even after optimization of the reaction conditions, complete conversion was still not achieved. Adjusting the substrate ratio is a common strategy to improve the reaction conversion in double substrate reactions such as transamination reactions. Therefore, we tested different ratios of the two substrates in an effort to shift the reaction equilibrium and further enhance the conversion. As shown in Figure 7, the conversion rates of $1 \mathrm{~b}$ and $3 \mathrm{a}$ reached $100 \%$ when the molar ratios of $1 \mathrm{~b}$ to $3 \mathrm{a}$ were $1: 8$ and $6: 1$, respectively. These results indicated that adjusting the substrate ratio was also effective in improving conversion in transamination-like reactions.

The total volume of the biocatalytic reaction mixture was $2 \mathrm{~mL}$. It contained purified $\mathrm{LDH}\left(1.0 \mathrm{mg} \cdot \mathrm{mL}^{-1}\right), \mathrm{NAD}^{+}(0.01 \mu \mathrm{M}), \mathrm{NH}_{4} \mathrm{Cl}(2 \mathrm{mM})$, tris-HCl buffer ( $\left.\mathrm{pH} 9.0\right)$, and two substrates which were added in different ratios. The reaction mixture was incubated at $30^{\circ} \mathrm{C}$ with shaking at $200 \mathrm{rpm}$ for $0-12 \mathrm{~h}$. All determinations were performed in triplicate, and error bounds represent $\pm \mathrm{sd}$. 

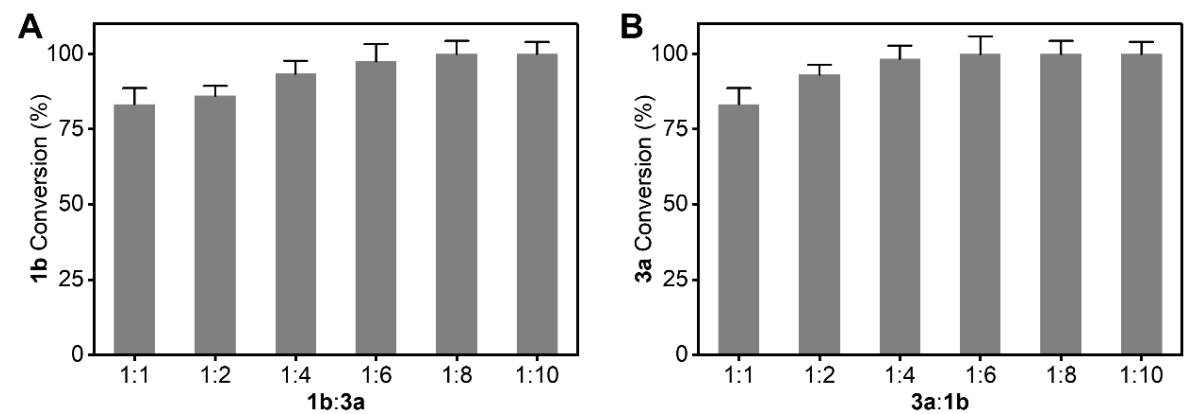

Figure 7. Effect of different substrate addition ratio toward the conversion rate. Effect of different substrate addition ratio toward the conversion rate of $1 \mathrm{~b}(\mathbf{A})$ and $3 \mathrm{a}(\mathbf{B})$.

\section{Materials and Methods}

\subsection{Strains, Plasmids, and Chemicals}

Leucine dehydrogenase (LDH) from Bacillus cereus was in our laboratory. Plasmid pET-28a (+) and Escherichia coli BL21 (DE3) were procured from Novagen (Nanjing, China) and used as the gene expression vector and host, respectively. Kanamycin, isopropyl$\beta$-D-thiogalactopyranoside (IPTG), 1-fluoro-2,4-dinitrophenyl-5-L-alanineamide (FDAA), $\mathrm{NAD}^{+}$, and NADH were obtained from TCI (Shanghai, China). $\alpha$-keto acids (4-methyl2-oxopentanoic acid, 3-methyl-2-oxobutanoic acid, 2-oxobutanoic acid, 3,3-dimethyl-2oxobutanoic acid, 2-oxopropanoic acid, 2-oxo-3-phenylpropanoic acid) and $\alpha$-amino acids (L-leucine, L-valine, L-2-aminobutyric acid, L-tert-leucine, L-alanine, L-phenylalanine) were purchased from J\&K Chemical (Beijing, China). All other chemicals were purchased from commercial sources, at least reagent grade, and were used without further purification.

\subsection{Protein Expression and Purification}

Escherichia coli BL21 (DE3) cells containing recombinant pET-28a (+) plasmids were cultured in Luria-Bertani (LB) medium with kanamycin $\left(50 \mathrm{mg} \cdot \mathrm{L}^{-1}\right)$ at $37^{\circ} \mathrm{C}$ and with shaking at $200 \mathrm{rpm}$ for $2 \mathrm{~h}$. Enzyme expression was induced with IPTG (final concentration $=0.2 \mathrm{mM}$ ) when the bacteria reached $\mathrm{OD}_{600}=0.6-0.8$. The cells were incubated at $20^{\circ} \mathrm{C}$ and with shaking at $200 \mathrm{rpm}$ for $12 \mathrm{~h}$. His-tagged enzymes were purified with an ÄKTA purifier system (GE Healthcare, Little Chalfont, UK). The cells were resuspended in buffer A (100 mM potassium phosphate, $150 \mathrm{mM} \mathrm{NaCl}$, and $20 \mathrm{mM}$ imidazole; $\mathrm{pH}$ 7.5) and disrupted with an ultrasonic cell disruption system (SCIENTZ-IID; Ningbo Scientz Biotechnology, Ningbo, Zhejiang, China) followed by centrifugation at $12,000 \mathrm{rpm}$ and $4{ }^{\circ} \mathrm{C}$ for $30 \mathrm{~min}$ to remove cell debris and obtain cell-free extracts. The latter were passed through a $0.22-\mu \mathrm{m}$ filter and loaded into a standard Ni-NTA affinity column (Thermo Fisher Scientific, Waltham, MA, USA) pre-equilibrated with buffer A. The column was then gradient-eluted with buffer B (100 mM potassium phosphate, $150 \mathrm{mM} \mathrm{NaCl}$, and $500 \mathrm{mM}$ imidazole; $\mathrm{pH}$ 7.5). Eluted fraction purity was determined by SDS-PAGE.

\subsection{Enzyme Activity Assay}

Enzyme activity was measured at $340 \mathrm{~nm}$ and at $30{ }^{\circ} \mathrm{C}$ using a MultiSkan GO UVspectrometer (Thermo Fisher Scientific). The standard assay mixture for the oxidative deamination reaction contained $5 \mathrm{mM} \alpha$-amino acids, $0.1 \mathrm{M}$ Tris- $\mathrm{HCl}$ buffer ( $\mathrm{pH}$ 8.5), and $0.2 \mathrm{mM} \mathrm{NAD}^{+}$. The reductive amination reaction was carried out in $1 \mathrm{M} \mathrm{NH} 4 \mathrm{Cl} / \mathrm{NH}_{4} \mathrm{OH}$ buffer ( $\mathrm{pH}$ 9.5) with $5 \mathrm{mM} \alpha$-keto acids and $0.2 \mathrm{mM} \mathrm{NADH}$. Both reactions were performed in a final volume of $200 \mu \mathrm{L}$ and initiated by the addition of limiting amounts of enzyme. One unit of enzyme activity $(1 \mathrm{U})$ was defined as the amount of enzyme which catalyzes the production (or consumption) of $1 \mu \mathrm{mol}$ of NADH per min under the standard assay conditions. Three sets of parallel experiments were performed for each experimental condition. All determinations were performed in triplicate, and error bounds represent $\pm \mathrm{sd}$. 


\subsection{Kinetic Parameters Analysis}

According to the enzymatic reaction equation, Michaelis-Menten equation: $\mathrm{V}=\left(V_{\max } * \mathrm{~S}\right) /\left(K_{\mathrm{m}}+\mathrm{S}\right)$, when $\mathrm{V}=0.5 V_{\max }, K_{\mathrm{m}}=$ [S]. It can be seen that $K_{\mathrm{m}}$ is equal to the substrate concentration when the initial rate of enzymatic reaction is half of the maximum rate $V_{\max }$. $V_{\max }$ represents the maximum reaction rate at a certain amount of enzyme. Kinetic parameters with respect to substrate $\alpha$-keto acids were evaluated in $\mathrm{NH}_{4} \mathrm{Cl} / \mathrm{NH}_{4} \mathrm{OH}$ buffer $(1 \mathrm{M}$; $\mathrm{pH} 9.5)$ at $30^{\circ} \mathrm{C}$ in the presence of $1-100 \mathrm{mM}$ substrates and $0.5 \mathrm{mM}$ NADH with the purified enzymes. Kinetic parameters with respect to substrate $\alpha$-amino acids were evaluated in Tris- $\mathrm{HCl}$ buffer $(0.1 \mathrm{M} ; \mathrm{pH} 8.5)$ at $30^{\circ} \mathrm{C}$ in the presence of 1-100 $\mathrm{mM}$ substrates and $0.5 \mathrm{mM} \mathrm{NAD}^{+}$with the purified enzymes. Kinetic parameters with respect to $\mathrm{NADH}$ were evaluated in $\mathrm{NH}_{4} \mathrm{Cl} / \mathrm{NH}_{4} \mathrm{OH}$ buffer $(1 \mathrm{M} ; \mathrm{pH} 9.5)$ at $30{ }^{\circ} \mathrm{C}$ in the presence of 0.1-0.5 mM NADH and $20 \mathrm{mM}$ 4-methyl-2-oxopentanoic acid with the purified enzymes. Kinetic parameters with respect to $\mathrm{NAD}^{+}$were evaluated in Tris- $\mathrm{HCl}$ buffer (0.1 M; pH 8.5) at $30^{\circ} \mathrm{C}$ in the presence of $0.1-0.5 \mathrm{mM} \mathrm{NAD}^{+}$and $20 \mathrm{mM}$ L-leucine with the purified enzymes. All reactions were performed in a final volume of $200 \mu \mathrm{L}$. After incubation at $30^{\circ} \mathrm{C}$ for $2 \mathrm{~min}$, the amount of enzyme solution was added to measure the absorbance change at a wavelength of $340 \mathrm{~nm}$, and the enzyme activity of LDH was calculated. Three sets of parallel experiments were performed for each experimental condition. All determinations were performed in triplicate, and error bounds represent $\pm \mathrm{sd}$.

\subsection{Reaction Conditions Optimization}

The total volume of the biocatalytic reaction mixture was $2 \mathrm{~mL}$. It contained purified $\mathrm{LDH}\left(1.0 \mathrm{mg} \cdot \mathrm{mL}^{-1}\right), \mathrm{NAD}^{+}(0.01-10 \mu \mathrm{M}), \mathrm{NH}_{4} \mathrm{Cl}(2-10 \mathrm{mM})$, tris- $\mathrm{HCl}$ buffer ( $\left.\mathrm{pH} 7.0-9.0\right)$ or $\mathrm{NH}_{4} \mathrm{Cl} / \mathrm{NH}_{4} \mathrm{OH}$ ( $\left.\mathrm{pH} 10.0-11.0\right)$, and substrates (20-120 mM). The reaction mixture was incubated at $30^{\circ} \mathrm{C}$ with shaking at $200 \mathrm{rpm}$ for $12 \mathrm{~h}$. Samples $(200 \mu \mathrm{L})$ were drawn at intervals and alkalized with $200 \mu \mathrm{L} \mathrm{NaOH}(10 \mathrm{M})$ to terminate the reaction. The solutions were then subjected to High Performance Liquid Chromatography (HPLC). All determinations were performed in triplicate, and error bounds represent \pm sd.

\subsection{Reaction Progress Monitoring}

The total volume of the biocatalytic reaction mixture was $2 \mathrm{~mL}$. It contained purified $\mathrm{LDH}\left(1.0 \mathrm{mg} \cdot \mathrm{mL}^{-1}\right), \mathrm{NAD}^{+}(0.01 \mu \mathrm{M}), \mathrm{NH}_{4} \mathrm{Cl}(2 \mathrm{mM})$, tris- $\mathrm{HCl}$ buffer $(\mathrm{pH} 9.0)$, and substrates $(100 \mathrm{mM})$. The reaction mixture was incubated at $30^{\circ} \mathrm{C}$ with shaking at $200 \mathrm{rpm}$ for $0-12 \mathrm{~h}$. Samples $(200 \mu \mathrm{L})$ were drawn at intervals and alkalized with $200 \mu \mathrm{L} \mathrm{NaOH}$ $(10 \mathrm{M})$ to terminate the reaction. The solutions were then subjected to High Performance Liquid Chromatography (HPLC). All determinations were performed in triplicate, and error bounds represent $\pm \mathrm{sd}$.

\subsection{HPLC Analysis}

The substrates conversion was determined with an Agilent 1260 HPLC (Agilent Technologies, Santa Clara, CA, USA). 1-fluoro-2,4-dinitrophenyl-5-L-alanine amide (FDAA) was applied to distinguish the absolute configuration of $\alpha$-amino acid products through precolumn derivatizing reaction [36,37]. The conversion rate of $\alpha$-amino acids was determined after derivatization with FDAA. A 5- $\mu \mathrm{L}$ reaction sample, $4 \mu \mathrm{L}$ of $1 \mathrm{M} \mathrm{NaHCO}_{3}$, and $20 \mu \mathrm{L}$ of $1 \%(w / v)$ FDAA in acetone were mixed and heated at $40{ }^{\circ} \mathrm{C}$ for $60 \mathrm{~min}$. Then, $4 \mu \mathrm{L}$ of $1 \mathrm{M} \mathrm{HCl}$ and $467 \mu \mathrm{L}$ of $40 \%(v / v)$ aqueous acetonitrile were added to the mixture. The latter was then passed through a $0.22-\mu \mathrm{m}$ filter and subjected to HPLC. The conditions for determining the conversion rate of $\alpha$-amino acids were as follows: Develosil ${ }^{\circledR}$ ODS-UG-5 column $(5 \mu \mathrm{m} ; 150 \mathrm{~mm} \times 4.6 \mathrm{~mm})$ (Phenomenex); mobile phase B $(5 \%(v / v)$ acetonitrile, $0.05 \%(v / v)$ trifluoroacetic acid, and $1 \%(v / v)$ methanol); mobile phase C $(60 \%(v / v)$ acetonitrile, $0.05 \%(v / v)$ trifluoroacetic acid, and $1 \%(v / v)$ methanol); linear gradient from $0 \%-100 \%$; mobile phase $\mathrm{C}, 45 \mathrm{~min}$ at $30{ }^{\circ} \mathrm{C}$; flow rate, $1.0 \mathrm{~mL} \cdot \mathrm{min}^{-1}$; injection volume, $20 \mu \mathrm{L}$; and UV detection at $340 \mathrm{~nm}$. The conditions for determining the $\alpha$-keto acids conversion rate were as follows: Diamonsil C18(2) column $(5 \mu \mathrm{m} ; 250 \mathrm{~mm} \times 4.6 \mathrm{~mm})$ 
(Phenomenex, Torrance, CA, USA); mobile phase A $(55 \%(v / v)$ methanol plus $0.1 \%(v / v)$ trifluoroacetic acid), $20 \mathrm{~min}$ at $30{ }^{\circ} \mathrm{C}$; flow rate, $0.8 \mathrm{~mL} \cdot \mathrm{min}^{-1}$; injection volume, $10 \mu \mathrm{L}$; and UV detection at $230 \mathrm{~nm}$. All determinations were performed in triplicate, and error bounds represent $\pm \mathrm{sd}$.

\section{Conclusions}

In this study, a novel transamination-like reaction was constructed based on the characteristic catalytic property of LDH to enable the simultaneous synthesis of target $\alpha$-amino acids and $\alpha$-keto acids without the need for a separate coenzyme regeneration system involving GDH or FDH. The thermodynamically unfavorable oxidation reaction was driven by the reduction reaction with the consumption of NADH. As a result, a 77-fold higher conversion was achieved from the transamination-like reaction compared with that achieved with the single-step oxidation reaction. Based on the analysis of kinetic parameters, we were able to explain the effect of combinations of amino group donors and acceptors on substrate conversion. Finally, the conditions of the transamination-like reaction were investigated using $3 \mathrm{a}$ and $1 \mathrm{~b}$ as model substrates. Under optimal conditions ( $\mathrm{pH}$ 9.0, $100 \mathrm{mM}$ substrate, $0.1 \mu \mathrm{M} \mathrm{NAD}^{+}$, and $2 \mathrm{mM} \mathrm{NH}_{4}{ }^{+}$), the conversion of $1 \mathrm{~b}$ increased from $42.0 \%$ to $90.3 \%$ and the TTN increased from $5.9 \times 10^{5}$ to $9.0 \times 10^{6}$. Furthermore, complete conversion to the target product was achieved by adjusting the substrate ratio. This artificial design of transamination-like reactions for the simultaneous production of $\alpha$ amino acids and $\alpha$-ketone acids can be applied to other types of amino acid dehydrogenases to expand the substrate scope and synthesize a wider range of valuable products.

Author Contributions: Conceptualization, X.M. and X.F.; data curation, X.M. and X.F.; formal analysis, X.M., T.W. and F.Z.; funding acquisition, X.M., Y.N. and Y.X.; investigation, X.M. and X.F.; methodology, X.M. and X.F.; project administration, Y.N. and Y.X.; resources, Y.N. and Y.X.; software, T.W. and F.Z.; supervision, X.M.; visualization, T.W. and F.Z.; writing-original draft, T.W. and F.Z.; writing - review and editing, X.M. All authors have read and agreed to the published version of the manuscript.

Funding: This work was supported by the National Key Research and Development Program of China (grant number 2021YFC2100100), the National Natural Science Foundation of China (NSFC) (grant numbers 21336009 and 21176103), and the National First-Class Discipline Program of Light Industry Technology and Engineering (grant number LITE2018-09).

Institutional Review Board Statement: Not applicable.

Informed Consent Statement: Not applicable.

Data Availability Statement: All datasets presented in this study are included in the article.

Conflicts of Interest: The authors declare no conflict of interest.

Sample Availability: Not applicable.

\section{References}

1. Najera, C.; Sansano, J.M. Catalytic asymmetric synthesis of alpha-amino acids. Chem. Rev. 2007, 107, 4584-4671. [CrossRef]

2. Basak, S.; Nader, S.; Mansy, S.S. Protometabolic reduction of NAD(+) with alpha-keto acids. JACS Au. 2021, 1, 371-374. [CrossRef] [PubMed]

3. Song, W.; Xu, X.; Gao, C.; Zhang, Y.; Wu, J.; Liu, J.; Chen, X.; Luo, Q.; Liu, L. Open gate of corynebacterium glutamicum threonine deaminase for efficient synthesis of bulky alpha-keto acids. ACS Catal. 2020, 10, 9994-10004. [CrossRef]

4. Galkin, A.; Kulakova, L.; Yoshimura, T.; Soda, K.; Esaki, N. Synthesis of optically active amino acids from $\alpha$-keto acids with Escherichia coli cell expressing heterologous genes. Appl. Environ. Microbiol. 1997, 63, 4651-4656. [CrossRef]

5. Penteado, F.; Lopes, E.F.; Alves, D.; Perin, G.; Jacob, R.G.; Lenardao, E.J. Alpha-keto acids: Acylating agents in organic synthesis. Chem. Rev. 2019, 119, 7113-7278. [CrossRef] [PubMed]

6. Chun, S.W.; Narayan, A.R.H. Biocatalytic, stereoselective deuteration of alpha-amino acids and methyl esters. ACS Catal. 2020, 10, 7413-7418. [CrossRef] [PubMed]

7. Moriwaki, H.; Resch, D.; Li, H.; Ojima, I.; Takeda, R.; Luis Acena, J.; Soloshonok, V. Inexpensive chemical method for preparation of enantiomerically pure phenylalanine. Amin. Acids. 2014, 46, 945-952. [CrossRef] 
8. Ogo, S.; Uehara, K.; Abura, T.; Fukuzumi, S. pH-dependent chemoselective synthesis of alpha-amino acids. Reductive amination of alpha-keto acids with ammonia catalyzed by acid-stable iridium hydride complexes in water. J. Am. Chem. Soc. 2004, 126, 3020-3021. [CrossRef] [PubMed]

9. $\quad$ Kang, H.Y.; Ji, Y.M.; Yu, Y.K.; Yu, J.Y.; Lee, Y.; Leet, S.J. Synthesis of alpha-ketobutyrolactones and gamma-hydroxy-alpha-keto acids. Bull. Korean Chem Soc. 2003, 24, 1819-1826.

10. Xie, Y.; Lou, R.; Zhi, L.; Mi, A.; Jiang, Y. DPAMPP in catalytic asymmetric reactions: Enantioselective synthesis of Lhomophenylalanine. Tetrahedron Asymmetry 2000, 11, 1487-1494. [CrossRef]

11. Xue, Y.-P.; Cao, C.-H.; Zheng, Y.-G. Enzymatic asymmetric synthesis of chiral amino acids. Chem. Soc. Rev. 2018, 47, 1516-1561. [CrossRef]

12. Simon, R.C.; Mutti, F.G.; Kroutil, W. Biocatalytic synthesis of enantiopure building blocks for pharmaceutical. Drug Discov. Today. 2013, 10, e37-e44. [CrossRef] [PubMed]

13. Turner, N.J.; O’Reilly, E. Biocatalytic retrosynthesis. Nat. Chem. Biol. 2013, 9, 285-288. [CrossRef] [PubMed]

14. Bornscheuer, U.T.; Huisman, G.W.; Kazlauskas, R.J.; Lutz, S.; Moore, J.C.; Robins, K. Engineering the third wave of biocatalysis. Nature 2012, 485, 185-194. [CrossRef]

15. Bornscheuer, U.T. Biocatalysis: Successfully crossing boundaries. Angew. Chem. Int. Ed. 2016, 55, 4372-4373. [CrossRef]

16. Yi, D.; Bayer, T.; Badenhorst, C.P.S.; Wu, S.; Doerr, M.; Höhne, M.; Bornscheuer, U.T. Recent trends in biocatalysis. Chem. Soc. Rev. 2021, 50, 8003-8049. [CrossRef]

17. Sheldon, R.A.; Woodley, J.M. Role of biocatalysis in sustainable chemistry. Chem. Rev. 2018, 118, 801-838. [CrossRef] [PubMed]

18. Savile, C.K.; Janey, J.M.; Mundorff, E.C.; Moore, J.C.; Tarn, S.; Jarvis, W.R.; Colbeck, J.C.; Krebber, A.; Fleitz, F.J.; Brands, J. Biocatalytic asymmetric synthesis of chiral amines from ketones applied to sitagliptin manufacture. Science 2010, 329, 305-309. [CrossRef] [PubMed]

19. Slabu, I.; Galman, J.L.; Lloyd, R.C.; Turner, N.J. Discovery, engineering, and synthetic application of transaminase biocatalysts. ACS Catal. 2017, 7, 8263-8284. [CrossRef]

20. Truppo, M.D.; Rozzell, J.D.; Moore, J.C.; Turner, N.J. Rapid screening and scale-up of transaminase catalysed reactions. Org. Biomol. Chem. 2009, 7, 395-398. [CrossRef]

21. Truppo, M.D.; Strotman, H.; Hughes, G. Development of an immobilized transaminase capable of operating in organic solvent. Chem CatChem 2012, 4, 1071-1074. [CrossRef]

22. Guo, F.; Berglund, P. Transaminase biocatalysis: Optimization and application. Green Chem. 2017, 19, 333-360. [CrossRef]

23. Koike, K.; Hakamada, Y.; Yoshimatsu, T.; Kobayashi, T.; Ito, S. NADP-specific glutamate dehydrogenase from Alkaliphilic Bacillus sp. KSM-635: Purification and enzymatic properties. Biosci. Biotechnol. Biochem. 1996, 60, 1764-1767. [CrossRef]

24. Li, H.M.; Zhu, D.M.; Hyatt, B.A.; Malik, F.M.; Biehl, E.R.; Ling, H. Cloning, protein sequence clarification, and substrates specificity of a leucine dehydrogenase from Bacillus sphaericus ATCC4525. Appl. Biochem. Biotechnol. 2009, 158, 343-351. [CrossRef] [PubMed]

25. Asano, Y.; Yamada, A.; Kato, Y.; Yamaguchi, K.; Hibino, Y.; Hirai, K.; Kondo, K. Enantioselective synthesis of (S)-amino acids by phenylalanine dehydrogenase from Bacillus sphaericus: Use of aatural and recombinant enzymes. J. Org. Chem. 1990, 55, 5567-5571. [CrossRef]

26. Ouyang, S.; Li, X.; Sun, X.; Ouyang, J.; Yong, Q. A thermostable leucine dehydrogenase from Bacillus coagulans NL01: Expression, purification and characterization. Process. Biochem. 2020, 90, 89-96. [CrossRef]

27. Yousefi, F.; Ataei, F.; Arab, S.S.; Hosseinkhani, S. Increase of Bacillus badius phenylalanine dehydrogenase specificity towards phenylalanine substrate by site-directed mutagenesis. Arch. Biochem Biophys. 2017, 635, 44-51. [CrossRef] [PubMed]

28. Xu, J.-M.; Cheng, F.; Fu, F.-T.; Hu, H.-F.; Zheng, Y.-G. Semi-rational engineering of leucine dehydrogenase for L-2-aminobutyric acid production. Appl. Biochem. Biotechnol. 2017, 182, 898-909. [CrossRef] [PubMed]

29. Zhou, J.P.; Wang, Y.L.; Chen, J.J.; Xu, M.J.; Yang, T.W.; Zheng, J.X.; Zhang, X.; Rao, Z.M. Rational engineering of Bacillus cereus leucine dehydrogenase towards $\alpha$-keto Acid reduction for improving unnatural amino acid production. Biotechnol. J. 2019, 14, 1800253. [CrossRef]

30. Zhou, F.; Mu, X.; Nie, Y.; Xu, Y. Enhanced catalytic efficiency and coenzyme affinity of leucine dehydrogenase by comprehensive screening strategy for L-tert-leucine synthesis. Appl. Microbiol. Biotechnol. 2021, 105, 3625-3634. [CrossRef]

31. Luo, W.; Zhu, J.; Zhao, Y.; Zhang, H.; Yang, X.; Liu, Y.; Rao, Z.; Yu, X. Cloning and expression of a novel leucine dehydrogenase: Characterization and L-tert-leucine production. Front. Bioeng. Biotechnol. 2020, 8, 186. [CrossRef]

32. Yin, X.J.; Liu, Y.Y.; Meng, L.J.; Zhou, H.S.; Wu, J.P.; Yang, L.R. Rational molecular engineering of glutamate dehydrogenases for enhancing asymmetric reductive amination of bulky $\alpha$-keto acids. Adv. Synth. Catal. 2019, 361, 803-812. [CrossRef]

33. $\mathrm{Wu}, \mathrm{T} . ; \mathrm{Mu}, \mathrm{X} . ; \mathrm{Xue}, \mathrm{Y} . ; \mathrm{Xu}, \mathrm{Y} . ; \mathrm{Nie}, \mathrm{Y}$. Structure-guided steric hindrance engineering of Bacillus badius phenylalanine dehydrogenase for efficient L-homophenylalanine synthesis. Biotechnol. Biofuels. 2021, 14, 207. [CrossRef] [PubMed]

34. Chen, J.; Zhu, R.; Zhou, J.; Yang, T.; Zhang, X.; Xu, M.; Rao, Z. Efficient single whole-cell biotransformation for L-2-aminobutyric acid production through engineering of leucine dehydrogenase combined with expression regulation. Bioresour Technol. 2021, 326, 124665. [CrossRef] [PubMed]

35. Jin, J.-Z.; Chang, D.-L.; Zhang, J. Discovery and application of new bacterial strains for asymmetric synthesis of L-tert-butyl leucine in high enantioselectivity. Appl. Biochem. Biotechnol. 2011, 164, 376-385. [CrossRef] 
36. Krishnamurthy, T. Chirality in microcystins. J. Am. Soc. Mass Spectrom. 1994, 5, 724-730. [CrossRef]

37. B'Hymer, C.; Montes-Bayon, M.; Caruso, J.A. Marfey's reagent: Past, present, and future uses of 1-fluoro-2,4-dinitrophenyl-5-Lalanine amide. J. Sep. Sci. 2003, 26, 7-19. [CrossRef] 